\title{
Effect of biostimulant Banzaï and fertilizer on the yield of cocoa trees in the locality of N'gouanmoinkro, Central Côte d'Ivoire
}

\author{
Hermann-Désiré Lallié1, Franck Zokou Oro² ${ }^{2}$ Nesma Nekkal $^{3}$ and Faiçal El Hattimy ${ }^{4}$ \\ ${ }^{I}$ Peleforo GON COULIBALY University, Biological Sciences Training and Research Unit, Department of Biochemistry-Genetics, \\ BP 1328 Korhogo, Côte d'Ivoire. \\ ${ }^{2}$ Peleforo GON COULIBALY University, Biological Sciences Training and Research Unit, Department of Plant Biology, BP \\ 1328 Korhogo, Côte d'Ivoire. \\ ${ }^{3}$ Polytechnic Mohammed VI University, Institute of Medical Sciences, Biologicals and Health Professions (ISMB-MS), Lot 660 \\ Hay Moulay Rachid 43150 Benguerir, Morocco. \\ ${ }^{4}$ Ibn Tofail University, Faculty of Sciences, Laboratory of Biology and Health, BP 14000, Maroc.
}

\begin{abstract}
In order to minimize production losses, and limit the use of chemicals, several organic products have been developed. The objective of this study is to assess the effect of biostimulant Banzai and fertilizer on cocoa tree productivity. Conducted in the department of Toumodi, this study took place in one device with a cocoa field that has received fertilizer in the last three years (DAE) and another that has received no fertilizer in the past three years (DSE). The results obtained showed that the plots that had been applied to Banzai produced significantly more pods than the control plots without application of the biostimulant. Compared to controls, the production rate of pods is greater than between 38 and $70 \%$ in the unprecedented fertilizer plots (DSE) and between 51 and $80 \%$ in plots with previous fertilizer (DAE). However, the production of pods in treated plots is more than three times high in the DAE than in the DSE. This study shows the positive impact of biostimulant use on cocoa yield. In addition, it shows that the use of fertilizers during the experiment could be abandoned with a view to greater use of organic products at the expense of chemicals that have a detrimental effect on the environment and on the long-term health of populations.
\end{abstract}

Keywords : Banzaï ; Biostimulant ; Cacao ; Productivité ; Côte d'Ivoire.

\section{INTRODUCTION}

Theobroma cacao $L$. is a tree of the Malvaceae family grown in many countries in the intertropical zone of America, Africa and Southeast Asia [1]. It is grown for the production of seeds used to prepare chocolate or cocoa butter [2].

Indeed, the cocoa sector plays an essential role in Côte d'Ivoire's economy. It is one of the main sources of income in the country [3-5]. Côte d'Ivoire, the world's largest producer, produces about 1,600,000 tons of cocoa annually, or nearly $40 \%$ of the world's supply [6-7].

However, many constraints lead to a considerable decline in Ivorian cocoa production [8]. In general, they can be classified in two categories of factors [8]. On the one hand, abiotic factors related to market price fluctuations and forest scarcity, and on the other hand, factors related to the action of diseases and pests of cocoa which are prevalent in all regions [8-9].
In Côte d'Ivoire, brown pod rot due to Phytophthora sp.and Swollen shoot disease caused by the Cocoa Swollen Shoot Virus (CSSV) are the two main diseases of Ivorian cocoa farmers that can result in yield or crop losses of up to 20 to $60 \%$ [10-14].

In order to fill this gap caused by these diseases and pests, Ivorian people use chemical products and fertilizers to optimize the yield of their cocoa plantations [15]. However, the use of these chemicals has a negative long-term impact on soil quality, including the health of the population and the environment [15-17].

In response to the decline in yield due to these biological aggressors and the limitation of the impact of chemicals on the environment and population health, new varieties of organic products have been introduced [18].

These are biostimulants define as substances or microorganisms whose function, when applied to plants or rhizosphere, is the stimulation of natural processes that promote and improve the absorption or 
use of nutrients, tolerance to abiotic stresses, quality or performance of the crop, regardless of the presence of nutrients [19-21]. They also provide solutions for fertilization and crop protection by acting on the ability of biological systems to adapt to bio-aggressor attacks or nutrient availability problems [19-21].

This study was conducted to determine the combined effect of the use of the biostimulant Banzai, the previous fertilizer and the fertilizer applied during the experiment on the production of cocoa pods.

\section{MATERIALS AND METHODS}

\subsection{Study site}

This study was carried out in N'gouanmoinkro (5-00$00 "$ North, 6-15-00"West), a village located in the subprefecture of Moronou in the department of Toumodi. With an area of about $2,837 \mathrm{~km}^{2}$, this department is located to $198 \mathrm{~km}$ from Abidjan, the economic capital and $34 \mathrm{~km}$ from Yamoussoukro, the political and administrative capital of Côte d'Ivoire [22]. Indeed, Toumodi is a department of high cocoa production which has an estimated annual cocoa production of nearly 9,000 tons [22].

\subsection{Materials}

The plant material was made up of Forastero-type cocoa trees at least 10 years old. The technical materials used are: the biostimulant Banzai; the chemical fertilizer SUPERCAO; an atomizer to apply the biostimulant to the cocoa trees; a decameter to delineate the experimental blocks; ribbons and paints to mark the trees.

\subsection{Méthodes}

The experimental device consists of a device with unprecedented no fertilizer (DSE) and another device with previous fertilizer (DAE). The previous nonfertiliser field is a field of cocoa farmers that has received no fertilizer in the last three years, while the previous fertilizer is a cocoa field that has received fertilizer in the last three years. Our two devices consisted of three Fischer blocks. Each block consists of six (6) randomized parcels rated T01, T02, T1, T2, T3 and T4 (Fig.1). Each experimental plot consists of twenty (20) cocoa trees.

○ T01 represents the control without application of Banzai but with fertilizer.

○ T02 represents the control without application of Banzai without fertilizer.
- T1 is a plot that has received three applications of Banzai with a fertilizer input.

- T2 is a plot that has received four applications of Banzai without fertilizer input.

○ T3 is a plot that has received three applications of Banzai without fertilizer input

- T4 is a plot that has received four applications of Banzai with fertilizer input.

\begin{tabular}{ll|l|l|l|l|l|l|l|l|l|} 
Block 1 & T01 & T4 & T02 & T2 & & T1 & & T3 \\
Block 2 & T02 & T1 & T3 & & T01 & & T4 & & T2 \\
\cline { 2 - 8 } Block 3 & T3 & & T4 & T01 & T2 & & T02 & T1 \\
\cline { 2 - 7 } & &
\end{tabular}

Fig.1. Expérimental device

\subsection{Observation and data collection}

The observations were made for nine months during July to February. The total number of pods is first counted per tree. The pods produced since Banzai's first treatment are counted and then marked with strings at the stalk. The numbered pods are not cumulative.

\subsection{Data analysis}

The descriptive analysis consisted of the production of histograms showing the number of pods produced per parcel and by observation time. It also consisted of the creation of boxplots showing the distribution of the cumulative number of pods produced per plot on all observations made. The comparative analysis was carried out using the Kruskal-Wallis test, which is an alternative test of the average comparison test (ANOVA). This test compared the average number of pods produced per plot and per device (DAE vs DSE). Finally, a classification of treatments based on their effectiveness was carried out following the KruskalWallis test when it was statistically significant. The statistical analysis was carried out using the Excel spreadsheet, IBM SPSS 20.0 software and R 3.2.5 software.

\section{RESULTS}

Figure 2 presents the pods produced per treatment and per month in the unprecedented device fertilizer. It shows a peak in pod production in the month of September. The month of February has the lowest number of pods produced. Over the entire observation period, the production of pods in plots treated with biostimulant Banzai is higher than that of untreated controls (T01 and T02). For the treated plots, the T4 
treatments (four applications of Banzai with fertilizer) and T1 (three applications of Banzai with fertilizer) were the most productive.

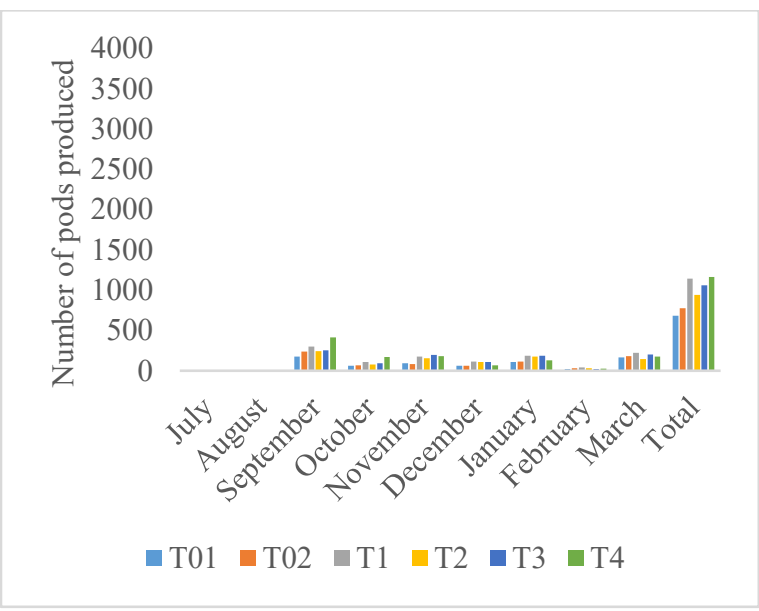

Fig.2. Dynamics of evolution of pod production by treatment and observation period in the unprecedented device fertilizer (DSE).

Figure 3 shows boxplots of the pod production by treatment in the unprecedented fertilizer (DSE) device. It shows that the production of pods is generally higher in parcels with biostimulant than in plots without product application. The Kruskal-Wallis test used to compare the production averages of the pods shows that there is a significant difference $(p<0.05)$ between treatments. The pods produced are higher in the plots with Banzai treatment than in the control plots.

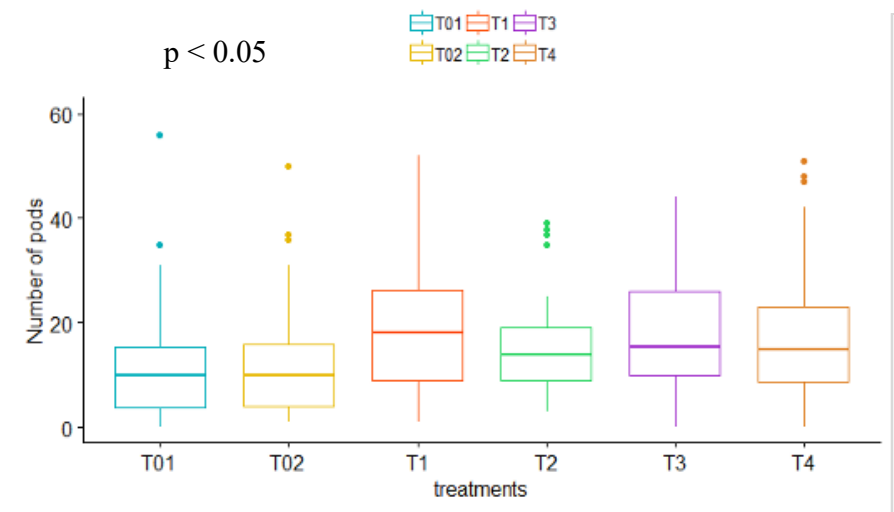

Fig.3. Boxplots of pods production by treatment in unprecedented fertilizer device.

The top-down step-by-step classification resulted in the grouping of treatments into two separate classes A and B. Class B, which includes the controls (T01 and T02), which represents the low-production class of pods. While, Class A, which includes all the treated parcels by biostimulant (T1, T2, T3 and T4) which represents the high pod production class (Table 1). This shows that the number of applications of the biostimulant (three and four applications) and the intake of fertilizer during the experiment did not have a significant impact on the yield of cocoa trees in the unprecedented fertilizer device.

Table 1: Classification of treatments based on average pod production in the DSE device

\begin{tabular}{ccc}
\hline Treatments & Average pods & Classification \\
\hline $\mathrm{T} 4$ & 19,4 & $\mathbf{A}$ \\
\hline $\mathrm{T} 1$ & 19,0 & $\mathbf{A}$ \\
$\mathrm{T} 3$ & 17,7 & $\mathbf{A}$ \\
\hline $\mathrm{T} 2$ & 15,7 & $\mathbf{A}$ \\
\hline $\mathrm{T} 02$ & 12,9 & $\mathbf{B}$ \\
$\mathrm{T} 01$ & 11,4 & $\mathbf{B}$ \\
\hline
\end{tabular}

Figure 4 shows the dynamics of pod production during the observation period in the device with previous fertilizer (DAE). The peaks in pod production were recorded in the month of September as in the unprecedented fertilizer device (DSE). Overall, the plots treated with biostimulant Banzai produced a greater number of pods than the control plots without application of the product. This result is identical to that obtained at the unprecedented fertilizer site (DSE). It therefore implies that the previous fertilizer (with or without fertilizer application for the three previous years) does not influence the contribution of the biostimulant Banzai which always remains positive on yield.

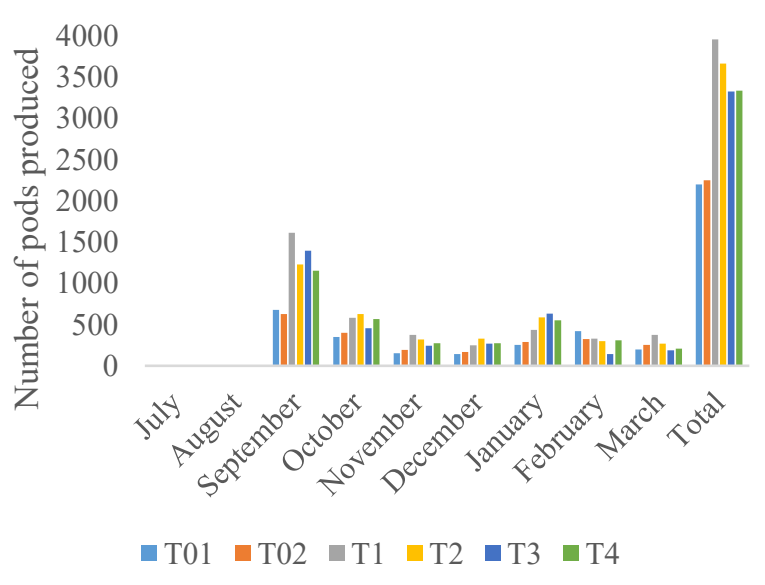

Fig.4. Dynamics of evolution of the number of pods produced per treatment and per month of observation in the device with previous fertilizer.

Figure 5 shows boxplots of the number of pods produced by treatment on all observations in the 
device with previous fertilizer (DAE). The KruskalWallis test used to compare production averages showed a significant difference $(\mathrm{p}<0.05)$ between treatments. Plots treated with biostimulant Banzai produced more pods than control plots without product application.

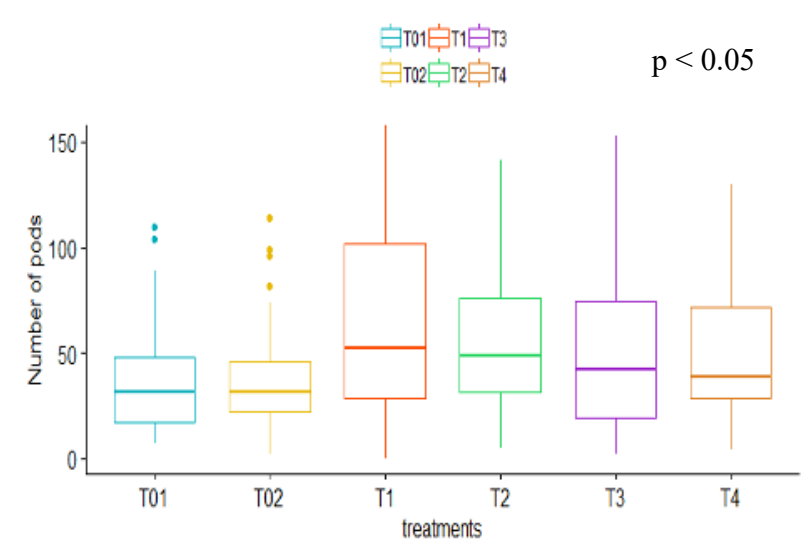

Fig.5. Boxplots of pods production by treatment in the DAE device

The prioritization of the parcels based on their performance allowed treatments to be grouped into two distinct classes A and B. The controls (T01 and T02) with the lowest production averages were exclusively in the class B. Class A, consisting of all treated plots, had the highest averages of pod production in this device with previous fertilizer (Table 2 ). This also shows that the number of applications of the biostimulant (three and four applications) and fertilizer during the experiment did not have a significant impact on the yield of the cocoa trees in this device.

Table 2: Classification of treatments based on average pod production in the DAE device

\begin{tabular}{ccc}
\hline Treatments & $\begin{array}{c}\text { Average of } \\
\text { pods }\end{array}$ & Classification \\
\hline T1 & 65,95 & A \\
\hline T2 & 61,05 & A \\
\hline T4 & 55,62 & A \\
\hline T3 & 55,38 & A \\
\hline T02 & 37,52 & B \\
\hline T01 & 36,60 & B \\
\hline
\end{tabular}

Figure 6 shows boxplots of pods production by device. The Kruskal-Wallis test used to compare the production averages of pods shows a significant difference $(p<0.05)$ between the devices. The averages of pods produced are more than three times higher on the plots of the device with previous fertilizer (DAE) than on the plots of the unprecedented fertilizer device (DSE).

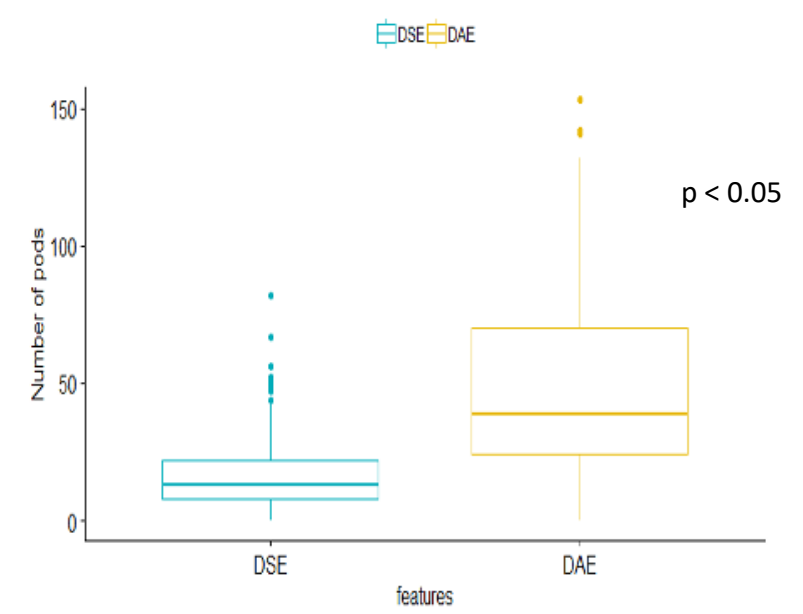

Fig.6. Boxplots of pods production by device.

\section{DISCUSSION}

The dynamics of evolution in the number of pods produced by treatment and observation period showed that the peak of production occurred during the month of September for both the unprecedented fertilizer device and the device with previous fertilizer. This can be explained by the rainy season of April-May-June. It favored the production of cherelles in the months of July and August and whose maturation in pods in optimal conditions allowed to have this peak production in the month of September [23].

The production of pods by treatment and whatever device with or without unprecedented fertilizer showed a significant difference between the plots treated with biostimulant Banzai and the control plots. Indeed, the plots that received the application of biostimulant Banzai have significantly produced more pods than the control plots that are without application of the biostimulant. This is consistent with the results of Faessel, which states that biostimulants increase the number of fruits by limiting the fall of immature or cherelle flowers and pods [19]. These results are also in line with those presented by Oro and his collaborators, on the effectiveness of the Banzai biostimulant in the production of pods in the context of Swollen shoot disease and in a context of brown rot of pods [12-14].

In addition, biostimulant promotes flowering, limits flower falls while stimulating the vigor of cocoa and its fruits against external diseases and stresses [19-20; 24-25]. Biostimulants contain algae extracts that affect the plant's natural physiological processes by promoting flowering and ripening of fruit [26-27].

The plots of the previous fertilizer device (DAE) have significantly higher pod production than 
unprecedented fertilizer plots (DSE). This result is in line with that presented by Effendy and his collaborators who have shown that the use of fertilizer in rural Indonesian cocoa farmers has a positive impact on cocoa yields and therefore farmers'incomes [28]. The supply of fertilizer to the DAE site in the three years prior to the experiment allowed the accumulation of fertilizer used in the soil, thus leading to an improvement in the productivity of cocoa trees. These results are consistent with those of Goulet and his collaborators who show that the accumulation of fertilizer in the soil improves the yield of cocoa plantations [29]. This may explain why the SUPERCAO chemical fertilizer used in this experiment has not been sufficiently accumulated in the soil to trigger a positive and significant effect on the yield of cocoa trees. This is how Ziteng Wang and his collaborators (2020) have shown that a $50 \%$ combination of organic fertilizers with $50 \%$ chemical fertilizers improves the quality and yield of tea in their study on optimizing the reduction of the use of chemical fertilizers based on an assessment of the associated environmental and economic benefits.

\section{CONCLUSION}

At the end of this study, it appears that the application of biostimulant Banzai improved the yield of cocoa trees. This biostimulant causes a significant increase in pod production of an average of $60 \%$ in treated plots compared to control plots without biostimulant application. With regard to the effect of the previous fertilizer, it should be noted that plots with preceding fertilizers are three times more capitalizing on the effect of biostimulant by the enhanced and accumulated fertilization of soils resulting in a significant improvement in the production of cocoa pods. However, the use of fertilizers during the experiment had few effect and could be abandoned for using biostimulants and especially in the decline in the use of chemicals which has a detrimental effect on the environment and on the health of populations in long term.

\section{BIBLIOGRAPHIC REFERENCES}

[1] R. Babin, Contribution à l'amélioration de la lutte contre les mirides du cacaoyer Sahlbergella singularis Hagl. (Hemiptera : Miridae). Influence des facteurs agroécologiques sur la dynamique des populations du ravageur. Thèse, Université Montpelier III - PAUL VALERIY, 246 p. (2009).
[2] G. Mossu, Le cacaoyer. Maisonneuve et Larose, Paris, 160 p. (1990).

[3] Banque Centrale des Etats d'Afrique de l'Ouest (BCEAO), Etude monographique sur la filière cacao dans l'UEMOA, 33 Pages. (2014).

[4] A.A. Assiri, A. Konan, K.F. N'Guessan, B.I. Kébé, K.E. Kassin, J.Y. Coulibaly, A.R. Yapo, G.R. Yoro and A Yao-Kouamé, Comparaison de deux techniques de replantation cacaoyère sur Antécédents culturaux non forestiers en Côte d'Ivoire. African Crop Science Journal, 23, No 4, pp. 365-378. (2015).

[5] Banque Mondiale, "Au pays du cacao comment transformer la Côte d'ivoire." Banque Mondiale, NW Washington, DC. (2019).

[6] S. Koua, N. Coulibaly, B. Alloué, Caractérisation des vergers et des maladies de cacao de la Côte d'Ivoire : cas des départements d'Abengourou, Divo et Soubré. Journal of Animal \&Plant Sciences. Vol.35, Issue 3 : 5706-5714. (2018).

[7] International Cocoa Council Organization (ICCO), Quarterly Bulletin of Cocoa Statistics. Vol. XLIV, No. 3, Cocoa year 2017/18. (2018).

[8] K. Kouakou, Diversité moléculaire du CSSV (cocoa swollen shoot virus) et épidémiologie de la maladie du swollen shoot du cacaoyer en Côte d'Ivoire. Thèse. Université Felix Houphouët-Boigny d'Abidjan. (2013).

[9] K. Coulibaly, B. Kébé, A. Aka, K. Kouakou, W. N'Guessan, G.M. Tahi, K.E. Kassin, S.B. Guiraud, M. Assi, B. Koné, K. N'Guessan, Bien lutter contre la pourriture brune des cabosses du cacaoyer en Côte d'Ivoire. Fiche technique cacaoyer $n^{\circ}$ 6, rapport CNRA. p.12. (2017).

[10] O.O.D. Dzahini, F.M. Amoah, Review : Over seventy years of a viral disease of cocoa in ghana : From researhers' perspective. Afr. J. Agric. Res. 5 (7) : 476-485. (2010).

[11] K. Kouakou, B. Kebe, N. Kouassi, S. Ake, C. Cilas, E. Muller, Geographical distribution of Cacao swollen shoot virus molecular variability in Cote d'Ivoire. Plant Dis. 96 : 1445-1450. (2012).

[12]F.Z. Oro, H-D. Lallié, S. Silué, D. Sanouidi and H.A. Diallo, Comparaison de l'effet du biostimulant Banzaï et de l'engrais sur la pourriture des cabosses du cacaoyer dans le département de Toumodi, Centre-Est de la Côte d'Ivoire. Journal of Animal and Plant 
Sciences (JAPS). Volume 45, Numéro 1, page 7822-7838. (2020A)

[13]F.Z. Oro, H-D. Lallié, C.A. N'Guessan, J. Kouadio, L. Diby, C. Kouamé and H.A. Diallo, Effect of Proper Management of Cocoa Plants on the Occurrence of Swollen Shoot Disease in Kipiri - Côte d'Ivoire. Journal of Experimental Agriculture International. 42 (3) : 159-166. (2020B).

[14]F.Z. Oro, H-D. Lallié, J.I. Fofana, P. BiZaouli and H.A. Diallo, Impact du Biostimulant Banzaï sur la production de cabosses dans le cas de la maladie du Swollen shoot du cacaoyer en Côte d'Ivoire. Afrique Sciences, 16, Issue 5 : 93-105. (2020C).

[15]E.J. Ano, A. Tahiri, Y.K.S. Diby, Y.M. Siapo, Evaluation des pratiques phytosanitaires paysannes dans les cacaoyères : Cas du département d'Abengourou (Est, Côte d'Ivoire). Journal of Animal and Plant Sciences, Vol. 38, Issue $1:$ 6159-6174. (2018).

[16] E.D. Okoffo, B.Y. Fosu-Mensah, C. Gordon, Contamination levels of organophosphorus and synthetic pyrethoïd pesticides in cocoa beans from Ghana, Food Control, Volume 73, Part B, Pages 1371-1378. (2017).

[17] O.A. Affum, S.O. Acquaah, S.D. Osae, E.E. Kwaansa-Ansah, Distribution and risk assessment of banned and other current-use pesticides in surface and groundwaters consumed in an agricultural catchment dominated by cocoa crops in the Ankobra Basin, Ghana. Science of the Total Environment. Volume 633. Pages 630-640. (2018).

[18] J. Flood, D. Guest, K. Holmes, P. Keane and E, Sulistyowati. Cocoa under attack. In Cocoa Futures. CABI-FEDERACAFE, Chincina, Colombia.164pp. (2004).

[19] L. Faessel, C. Gomy, N. Nassr, C. Tostivint, C. Hipper, A. Dechanteloup, Produits de stimulation en agriculture visant à améliorer les fonctionnalités biologiques des sols et des plantes. Étude des connaissances disponibles et recommandations stratégiques. Bio by Deloitte et RITTMO Agroenvironnement pour le ministère de l'Agriculture, de l'Agroalimentaire et de la Forêt. 148 p. (2014).

[20] European biostimulants industry council (EBIC), Promoting the biostimulant industry and the rule of plant biostimulants in making agriculture more sustainable. (2014). (http://www.biostimulants.eu/).

[21] A. R. Dehkordi, R.S. Roghani, S.M. and B. Asghari, Effects of biostimulants on morphophysiological traits of various ecotypes of fenugreek (Trigonella foenum-graecum L.) under water deficit stress. Scientia horticulturae. Volume 283. 110077. (2021).

[22] Agence Ivoirienne de Presse (AIP), Monographie du département de Toumodi. Abidjan.Net. Date de visite :22/12/2018. 5p. (2013).

[23] Centre National de Recherche Agronomique (CNRA), Bien cultiver du cacaoyer en Côte d'Ivoire. Fiche technique cacaoyer. p. 1-4. (2009).

[24] Callivoire, Biostimulant Banzaï. Rapport Callivoire. p-2. (2017)

[25] M. Ricci, L. Tilbury, B. Daridon, K. Sukalac, General Principles to Justify Plant Biostimulant Claims. Front. Plant Sci. 10 : 494. (2019).

[26] R. Bulgari, A. Trivellini, A. Ferrante, Effects of two doses of organic-extract based Biostimulant on Greenhouse Lettuce grown under increasing $\mathrm{NaCl}$ concentrations. Front. Plant Sci. 9 : 1870. (2019).

[27]G. Mannino, C. Campobenedetto, I. Vigilante, V. Contartese, C. Gentile et C.M. Bertea, The application of a plant biostimulant based on seaweed and yeast extract improved tomato fruit development and quality. Biomolecules;10 (12) : 1662. (2020).

[28]Effendy, M.F. Pratama, R.A. Rauf, M. Antara, M. Basir-Cyio, Mahfudz and Muhardi, Factors influencing the efficiency of cocoa farms: A study to increase income in rural Indonesia. Plos One. 14 (4): e0214569. (2019).

[29]M. Goulet, A. N'Dayegamiye et M. Laverdière, Les sciences du sol au 21e siècle. Centre de recherche et d'expérimentation en sols, Ministère de l'Agriculture, des Pêcheries et de l'Alimentation du Québec, 2700 Einstein, Sainte-Foy, Québec, Canada G1P 3W8. 110p. (1997).

[30]Z. Wang, Y. Geng, T. Liang, Optimization of reduced chemical fertilizer use in tea gardens based on the assessment of related environmental and economic benefits. Sci Total Environ ;713 :136439. (2020). 